\title{
NumERICAL SimUlation OF VENTILATION POTENTIAL IN TRADITIONAL OMANI HOUSE: BAIT AL KHANDAQ AS AN EXAMPLE
}

\author{
Hayder. M. Khan*, Saleh. Al-Saadi, Naima. Benkari, and Aliya Al-Hashim \\ Department of Civil and Architectural Engineering, Sultan Qaboos University, Muscat, Oman
}

\begin{abstract}
The use of cooling systems has increased because of drastic changes introduced after the oil revolution in the local architecture by using modern building designs and practices that may not suit Oman's climate. The traditional architecture in this country is characterized by its passive cooling design features, which the locals fine-tuned through trial and error. These sustainable passive design practices developed over the ages have the ability to provide healthy and comfortable spaces for their occupants while preserving environmental and natural resources. These strategies are still evident in many traditional settlements and buildings in Oman. The present research evaluates the effect of natural ventilation in achieving thermal comfort in traditional Omani houses. For this purpose, a traditional house in a hot-arid climate zone with vernacular architecture typology was chosen as a case study. Computational Fluid Dynamics (CFD) was used to model the house and analyse the airflow and temperature levels in its spaces. The results show the efficiency of such a design to enhance natural ventilation and thermal comfort in similar geo-climatic regions.
\end{abstract}

Keywords: CFD; Traditional Architecture; Natural Ventilation; Thermal Comfort.

$$
\text { محاكاة رقمية لإمكانيات التهوية في المنزل العماني التقليدي: بيت الخندق نموذجا }
$$

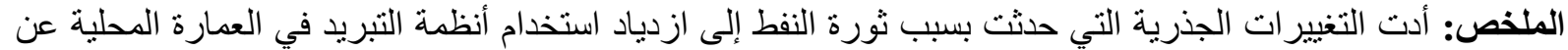

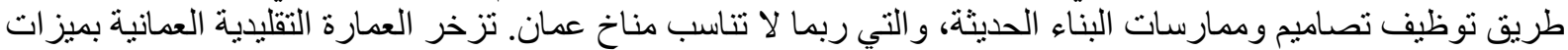

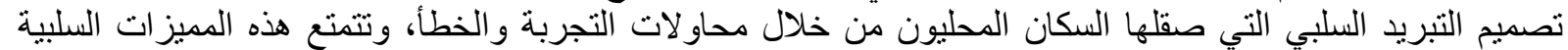

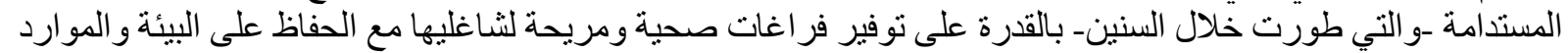

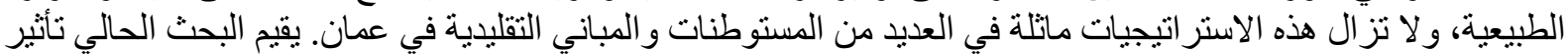

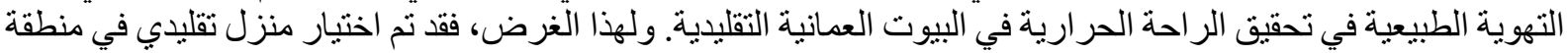

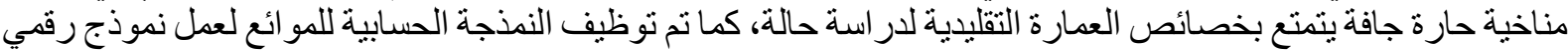
للمنزل ولتحليل مستويات تدفق الهو اءو ودرجة الحرارة في فر اغاته، وقد أظهرت التهات النتائج كفاءة مثل هذا التصميم في تعزيز التهوية الطبيعية و الر احة الحر ارية في مناطق مناخية وجغر افية مماثلكة.

الكلمات المفتاحية: داينميكا الموائع الحسابية؛ البناء التقليدي؛ التهوية الطبيعية؛ الراحة الحرارية.

*Corresponding author’s e-mail: khan@squ.edu.om 


\section{NOMENCLATURE}

$\begin{array}{ll}\mathrm{e} & \text { Expectancy factor } \\ h_{c} & \text { Heat Transfer Coefficient }\left(\mathrm{Wm}^{-2} \cdot \mathrm{K}^{-1}\right) \\ \mathrm{F}_{\mathrm{i}} & \text { Shape factor } \\ f_{c l} & \text { Garment insulation factor }(\mathrm{clo}) \\ \mathrm{MRT} & \text { Mean Radiation Temperature }(\mathrm{K}) \\ \text { Met } & \text { Metabolic rate (met) } \\ \mathrm{PMV} & \text { Predicted Mean Vote } \\ \mathrm{PPD} & \text { Predicted Percentage Dissatisfied } \\ P_{v} & \text { Vapor pressure of water vapor }(\mathrm{mb}) \\ \mathrm{T} & \text { Air temperature }\left({ }^{\circ} \mathrm{C}\right) \\ \mathrm{T}_{\text {wall }} & \text { Wall temperature }\left({ }^{\circ} \mathrm{C}\right) \\ \mathrm{T}_{\mathrm{cl}} & \text { Cloth temperature }\left({ }^{\circ} \mathrm{C}\right) \\ W_{\text {ork }} & \text { Active work }\left(\mathrm{W} \mathrm{m}^{-2}\right)\end{array}$

\section{INTRODUCTION}

Civilization in Oman goes back a thousand years, evident in many built settlements around the country. These settlements had desert architecture consisting of courtyard houses with thick walls and several vents, known locally as "'farkha' used to provide ventilation and thermal comfort by increasing airflow in the inner rooms. However, in the last fifty years, the oil sector has enriched the economy in Oman, leading to drastic population growth, hence the increased need for buildings. These buildings were built using modern designs that are not sustainable nor responsive to the local climate, and are dependent mainly on mechanical systems to provide thermal comfort. According to an interview conducted by (Gharibi 2014), most of the houses in Oman do not include thermal insulation, and air conditioning units work for an average of 17.5 hours during the day. The field survey from (Abdul Majid et al. 2014) shows that $100 \%$ of the bedrooms in the houses are equipped with air-conditioning units set to run at a relatively lower temperature equal to $21^{\circ} \mathrm{C}$. This relatively low-temperature thermostat setting, alongside other factors, has increased energy consumption in Oman by fifteen times during the thirty years from 1980-2010. Around $77 \%$ of this energy goes to the building sector, with $48-55 \%$ used in the housing sector, and $80 \%$ of this share is dedicated to running air conditioning systems (Gharibi 2014; Krarti and Dubey 2017; Alalouch et al. 2019; Al-Saadi and Al-Jabri 2020; Al-Saadi 2021). In order to bring these very high values to more reasonable and sustainable levels, there is a need to focus on reducing the use of air conditioning in houses to reduce energy consumption, especially with the prediction that energy consumption will increase in the coming years due to the lack of local building energy code, 'Oman's population growth and the weak consumption consciousness due to subsidized energy tariff. This extravagant energy consumption affects the environment, dilapidating the non-renewable energy resources, while constituting a heavy load on the national economy, where the energy subsidies are equal to $8.9 \%$ of the Omani Gross Domestic Product
(GDP) (Krarti and Dubey 2017).

Researchers are increasingly advocating for the study of vernacular architecture to generate a more sustainable built environment (Almatawa, Elmualim, and Essah 2012). However, in Oman, a few works have examined the environmental properties of vernacular architecture. The research of (Al-Hinai, Batty, and Probert 1993) is among the earliest of these studies, where four climatic regions were identified in Oman, along with a unique house typology for each region. These climatic regions vary from hot and humid along the north coast to bitterly cold on the high mountains. Most of the populated areas in Oman are in hot and arid regions, such as in Muscat and its surroundings, where the courtyard house is a popular housing typology for the hot arid climate (Egan 1975). The traditional building materials and technology relied on thick/dense walls and roofs to absorb the heat during the day and release it when the air temperatures drop during the night while losing part of the heat to the sky during the night through longwave radiation. These houses use vents on both inner and outer walls and along the courtyard to facilitate the convection in rooms. Furthermore, in the Muscat region, there are times when sea or land breezes will be active during the day and night and in these times the air temperature will be relatively lower than the daily average. During these times, the convection inside the building will be essential in providing thermal comfort. The vents, windows, and courtyard will also enhance the ventilation rate (Damlūji 1998; Scudo 1988). The present paper aims to reveal the mechanisms through which the architectural typology and components generate indoor thermal comfort.

Thermal comfort can be defined as "the condition of mind that expresses stratifications with the thermal environment, it requires subjective evaluation" (Szokolay 2012). The thermal comfort can be calculated using the Predicted Mean Vote (PMV) method (Fanger 1970). The value of PMV represents the reaction of a building's occupants to the thermal environment on a scale of seven points (-3: cold, -2 : cool, -1 : slightly cool, 0 : neutral, 1 : slightly warm, 2 : warm, 3: hot). The values calculated by equations consider various physical properties like activity level, clothes, temperature, humidity, etc. The values depend on physiological variables and show how people adapt to their climate with their physical properties. An example of the adaptation is how the people of hot arid areas feel comfortable even in relatively high temperatures $\left(28{ }^{\circ} \mathrm{C}\right)$ (Givoni 1998). This was confirmed by the thermal comfort survey done by Nicol in Baghdad (Nicol 1974), where he found out that some locals can feel comfortable at a relatively high temperature equal to $32^{\circ} \mathrm{C}$, which can be achieved by increasing the convection (air movement) in the room. The adaption effect made Fanger update his method to simulate the thermal comfort in non-airconditioned buildings in a warm area by using the expectancy factor (P. Ole Fanger and Toftum 2002). 
The present research will use the PMV method to judge the role of the openings in the vernacular house in enhancing the thermal comfort inside a traditional Omani house (Bait Khandaq) in the Al-Batinah region during a day in April with a temperature daily average of $29{ }^{\circ} \mathrm{C}$ and daily range $12{ }^{\circ} \mathrm{C}$. The house was built following a traditional typology and received several additions and transformations during different times in the last two hundred years. The Computational Fluid Dynamics (CFD) technique simulates the thermal condition and airflow in and around the house. This technique was used to study the natural ventilation in vernacular architecture in similar or close climatic conditions, such as in the south of Iran for instance (Heidari, Sahebzadeh, and Dalvand 2017). This technique to examine natural ventilation is preferred over other methods due to its flexibility (van Hooff and Blocken 2010). The present paper will begin by describing the house's architectural properties and the numerical techniques used; then, it will present the results by focusing on the indoor thermal comfort, before addressing the main conclusion of the research.

\section{THE HOUSE}

The house known as Bait al-Khandaq is part of the traditional settlement of Hujrat Musalmat in Wadi Al Ma'awil, located south of Muscat. The house was initially built as a one-level building in the early nineteenth century, then it was extended and a second level was added. In recent years, this house was surveyed by researchers and students from the civil and architectural engineering department in Sultan Qaboos University (Naima Benkari 2015). They documented the house architecturally and photographically, recorded its building structure and materials, and measured its indoor thermal conditions (Figure 1).

Many of the typical architectural element of traditional houses in the Al-Batinah region is shown in this house, such as the courtyard, thick walls, and air vents. The house has a bulky structure with walls made of earthen brick and plaster, with a thickness that can reach over $70 \mathrm{~cm}$ on some walls. This thickness was necessary to provide thermal inertia to keep the indoor cool enough until midday. The thickness usually decreases at the first level to give extra space for supporting the ceiling beams and lighten the weight to be supported by the main walls on the ground floor. Furthermore, the external walls are usually painted with a light colour. The house has a flat roof to increase radiant cooling (Al-Hinai, Batty, and Probert 1993; Damlūji 1998) and is surrounded by a parapet high enough to cover most of a standing person, mainly for privacy. The upper floors are constructed using a structure made of date palm trunks, cut in half or four, covered with palm leaves matting, supporting the massive layer of mud and small rocks covered with locally made lime-based plaster (Sarooj) (Meddah et al. 2020).

The house's floor is paved with natural earthen materials as well. The house is rectangular, with a rectangular courtyard located at the centre of the house (Table 1). A semi-open gallery surrounds the courtyard and constitutes a transition area distributing the circulation to the rooms. The rooms, with variable lengths and limited width, are organized around the courtyard. Their width is limited to less than 3 metres due to the size of the palm tree poles.
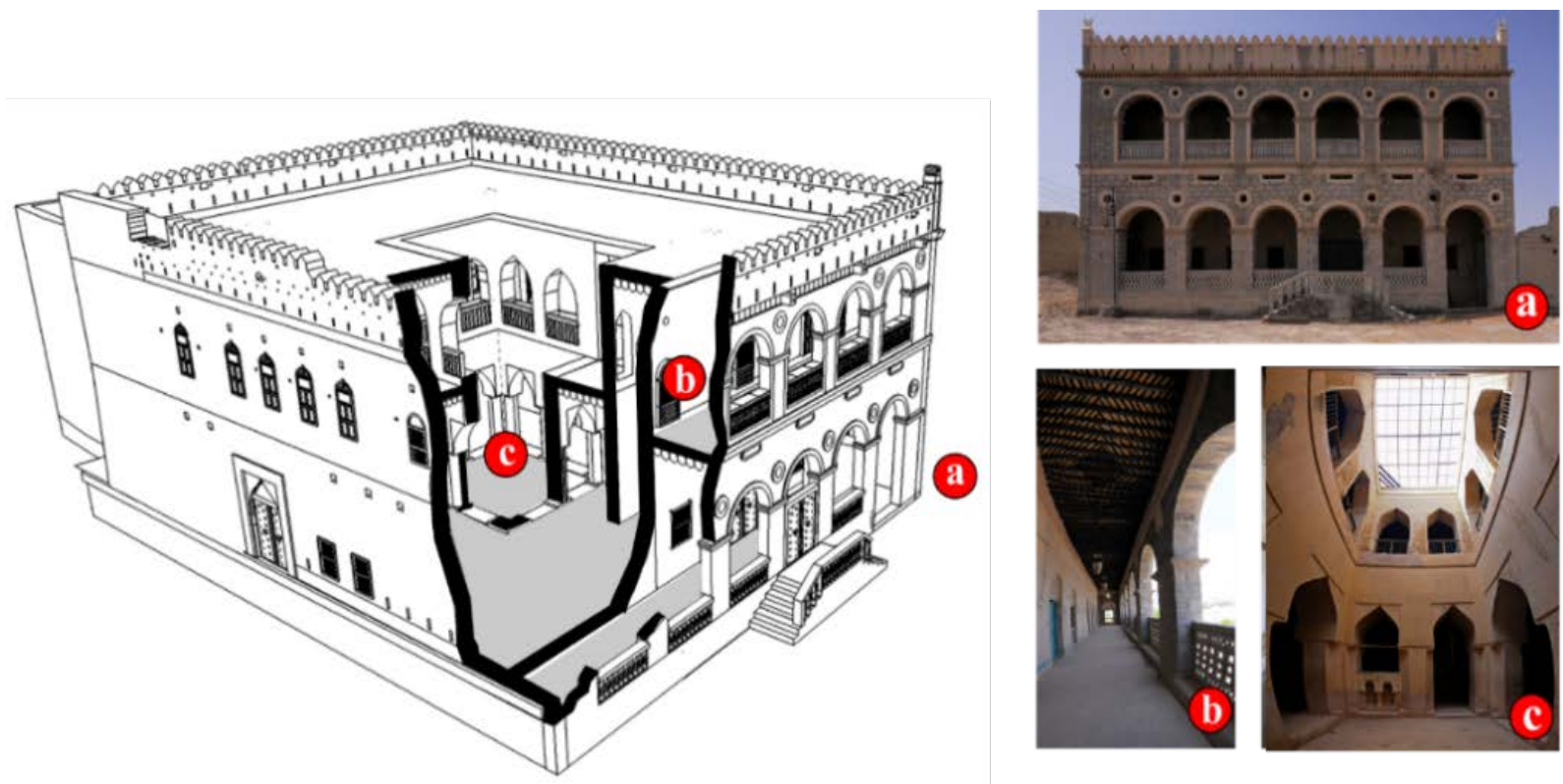

Figure 1. Bait al Khandaq Perspective (N. Benkari 2017). 
Table 1. Building parameters.

\begin{tabular}{ll}
\hline Building elements & Value \\
\hline House area & $510 \mathrm{~m}^{2}$ \\
Courtyard Area & $25 \mathrm{~m}^{2}$ \\
Windows surface area & $1-1.6 \mathrm{~m}^{2}$ \\
Vent surface area & 0.006 to $0.06 \mathrm{~m}^{2}$ \\
Wall structure & Sarooj + mud brick + Sarooj (thermal conductivity $0.75 \mathrm{~W} / \mathrm{mK})$ \\
Roof structure & Rammed earth + grass + Wood derivatives (thermal conductivity $0.3 \mathrm{~W} / \mathrm{mK}$ ) \\
Floor & Hardstone + soil earth (thermal conductivity $1.2 \mathrm{~W} / \mathrm{mK})$ \\
Room width & 2.8 to $3 \mathrm{~m}$ \\
Circular vent diameter & $20 \mathrm{~cm}$ \\
Number of rooms & 8 \\
Number of gallery or corridor & 2 (external+ internal)
\end{tabular}

For the same reason, similar widths can be found in the houses around the Arabian gulf (Kay 1991). The rooms have a high ceiling to provide enough space for the hot air to stagnate at the top, without too much accommodating of the room's users before it is exhausted through the vents. The openings in the rooms are located at two different levels in the external walls. The lower windows and small slit vents are near the floor (30-50 $\mathrm{cm}$ above the floor). They are the source of airflow in the room and control the thermal sensation, as the local people usually sit close to the floor. The windows are elongated with no glass. Wooden shutters are used to reduce the room's solar irradiation. Circular vents are usually pierced higher in the external walls and those adjacent to the gallery. They are used to exhaust the hot air, stagnating at the top of the room, and facilitate cross ventilation. The walls overlooking the courtyard of the house may contain doors and vents only. There are small rectangular slit openings $(30 \times 10 \mathrm{~cm})$ in the roof's parapet that provide an air jet to cool the roof surface during the daytime. The roof is commonly used for sleeping during summer nights, and these slit openings may increase the airflow, which improves thermal comfort. The daily weather in the region is characterized by sea and land breezes during the day and night, where the air temperature drops below the average. To take advantage of these breezes, the rooms in the upper level are equipped with more openings to provide higher airflow for the residents. The courtyard has several functions and properties. It enhances the natural ventilation and stores the cool air generated from longwave heat loss from the roof to the sky during the night. The cool air can flow from the courtyard to the rooms, through the vents, then leave the rooms through the openings in the external walls. However, most of the time, the house depends on sea and land breezes. The house does not include a wind catcher or basement, similar to other houses in other parts of AlBatinah. This may happen due to tropical storms that are common in this area. Furthermore, the house is located in a village with a building fabric that is not dense, and it is exposed to the sun from four directions.

\section{METHODOLOGY}

This paper aims to examine how the openings can affect the thermal comfort in different room parts. Several software and practical methods can be used to predict the thermal comfort in the room; however, only the CFD can show the spatial variations of thermal comfort resulting from the small vents that are distributed all around the room. The CFD divided the space into several cells (grid/mesh), from which the CFD solver constructs a control volume (finite volume). In every control volume, the software will solve some unsteady second-order discretized momentum, mass and energy conservation equations. These equations are closed by using turbulence models, Reynolds-Averaged Navier-Stokes equations $(\mathrm{k}-\varepsilon)$. This model comes in different versions. For this paper, realizable $\mathrm{k}-\varepsilon$ turbulence models by Shih et al.(Shih et al. 1995) were used. The turbulence in the boundary layer volume near walls was modelled using all $\mathrm{y}^{+}$wall treatment models keeping the value of $\mathrm{y}^{+}$ around one in regions inside the house due to the relatively low air velocity. One of the natural ventilation features is the existence of the temperature differences between the air and the surfaces; however, they are limited. For this, the Boussinesq approximation was used to calculate the changes in the air density. This method is more efficient than others because it requires less computational power.

Figure 2 shows the house modelled inside an atmospheric boundary layer wind tunnel with computational domain dimensions taken from the benchmark of Franke et al. (Franke et al. 2011), where a simulation for atmospheric boundary layer for flow around a courtyard flow is used in a number of papers like (Shao, Walker, and Woolliscroft 1993; Rajapaksha, Nagai, and Okumiya 2003). The boundary conditions (velocity, etc.) sets are according to the suggestions of (Richards and Hoxey 1993) to simulate the atmospheric boundary layer. Table 2 presents the initial and boundary conditions. Due to the significant role of solar radiation in thermal comfort, the solar irradiation on the building surfaces was modelled using a solar load model. This model calculates the solar 
intensity according to time, date, and geographic location. The heat transfer by radiation between surfaces can be found by applying a surface-to-surface transfer model (S2S). Also, the grey thermal radiation model is used to make radiation properties independent from the wavelength. The inlet air conditions as velocity, turbulent kinetic energy, and turbulent dissipation rate are defined using a user-defined function and based on the equations from (Richards and Hoxey 1993). The simulation was done in wellvalidated software Star CCM+ version 2021.1. The model was validated against the experimental works of other researchers for similar cases of mixed convection flow as shown in Figure 3 as the comparison between experimental and CFD for vertical temperature distribution in enclosed space under mixed convection move from inlet to outlet on different levels. The grid distribution is set using a polyhedral mesh (arbitrary polyhedral). This type of mesh (i.e., a group of cells) is non-uniform unstructured, and it was selected because of its computational efficiency and faster solution convergence. A prism layer is constructed next to the surfaces to prevent cell deformation and enhance the solution by making the gridline normal to the surface with high gradients for the velocity. Local refinement for the mesh was used in places in the house with a small dimension like an air vent. The grid sizes range from $3 \mathrm{~m}$ in the sides of the domain far from the house to $0.05 \mathrm{~m}$ in the air vents and windows. The grid numbers are approximately 19 million grids, with 10 million in the house and another 9 million in the outer region. It takes several days to complete one simulation using multi-core Xenon dual-CPU equipped in a workstation pc.

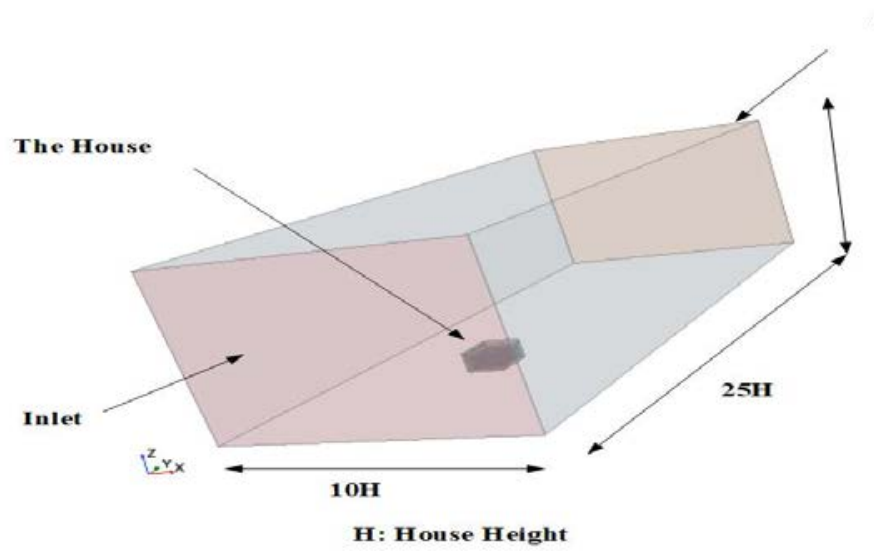

(a) The domain

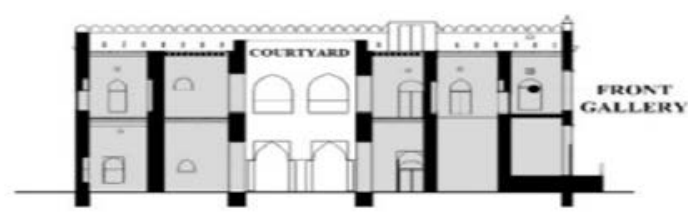

(d) Section $\mathbf{X}-\mathbf{X}$

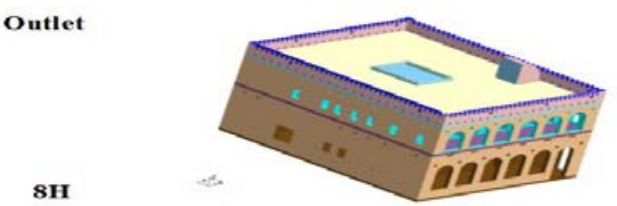

(b) Isometric view of Bait Al-Khandaq

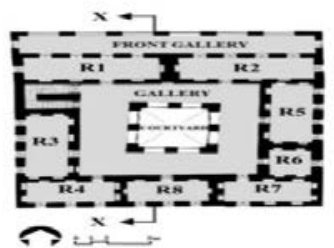

(c) Isometric view of Bait Al-Khandaq

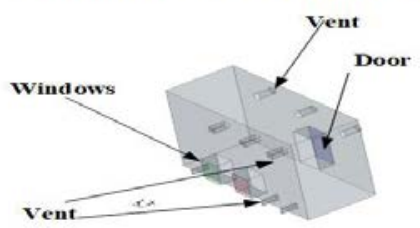

(d) Air volume in $R 5$

Figure 2. The Computational model.

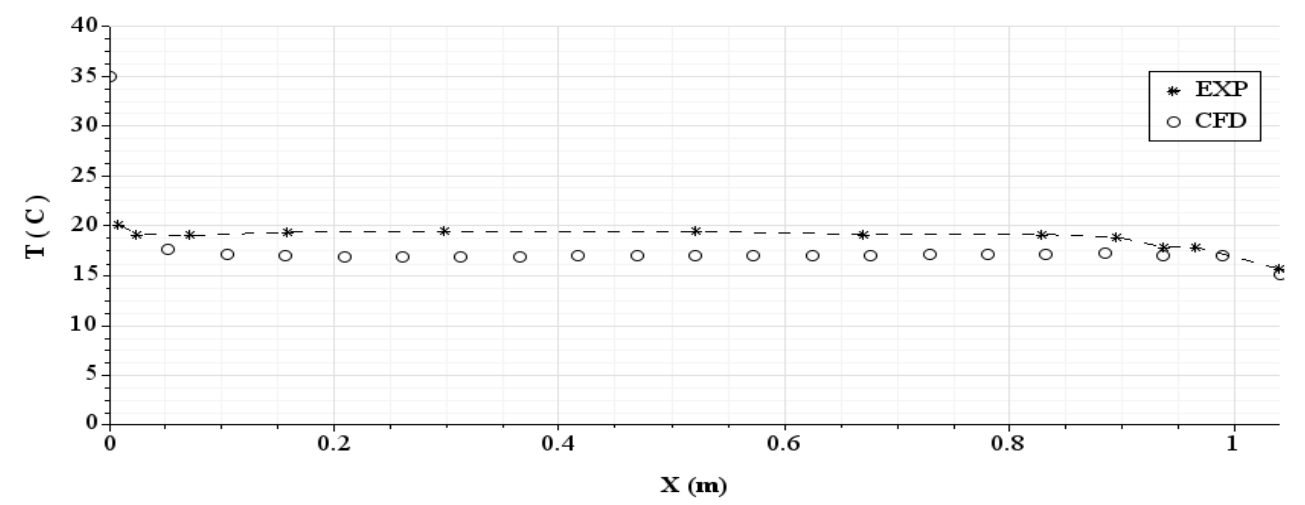

Figure 3. Comparison for the temperature distribution along the vertical axis between experimental work from (BLAY 1992) and CFD simulation for 
Table 2. Assumptions related to the computational model.

\begin{tabular}{ll}
\hline The condition & Value \\
\hline Initial conditions & The temperature at room $36{ }^{\circ} \mathrm{C}$ \\
Inlet condition & Velocity inlet Wind speed $5 \mathrm{~m} / \mathrm{s}$, temperature $28{ }^{\circ} \mathrm{C}$ \\
Sky temperature & Temperature $=0.0552$ (Tair) 1.5 \\
Outlet & Pressure outlet \\
Boundary conditions & Building wall surfaces to act as no-slip wall, domain surface slip wall \\
Wall and roof radiation properties & Brown scratch brick (emissivity=0.8, reflectivity= 0.2, transmissivity = $)$ \\
Time and date & Date: $01 / 04 / 2020$, Time $12: 00 \mathrm{PM}$ \\
Geographic location & Lat $23.4^{\circ}$, long $57.8^{\circ}$ \\
Garment insulation & 0.57 \\
Expectancy factor & 0.7 \\
metabolic rate & 1 met \\
Relative humidity (RH\%) & $20 \%$ (set as constant) \\
Time step and duration & $0.1 \mathrm{~s}$ for $20 \mathrm{~s}$ \\
\hline
\end{tabular}

The simulation outputs are air temperature values, air velocity, and mean radiant temperature of the building surfaces (MRT), which are necessary to predict thermal comfort. MRT accounts for the average radiation from the room surfaces to the centre of the room, and it can be calculated using the following equation,

$T_{R}=\sum_{i=1}^{4} T_{\text {wall } i} F_{i}$

where $F_{i}$ is the shape factor and $\mathrm{T}_{\text {wall }}$ is the walls surface temperatures; the value of $\mathrm{T}_{\mathrm{R}}$ (MRT) is used to find the $\mathrm{L}_{\mathrm{t}}$, which is the thermal load on the human body as:

$$
\begin{aligned}
& L_{t}=\text { Met }-W_{\text {ork }}-\left[3 . 9 6 * 1 0 ^ { - 8 } * f _ { c l } \left(T_{c l}+\right.\right. \\
& 273)^{4}-\left(T_{R}+273\right)^{4}+f_{c l} * h_{c}\left(T_{c l}-T\right)+3.05 * \\
& 10^{-3}\left(5733-6.99\left(M e t-W_{\text {ork }}\right)-P_{v}\right)+ \\
& 0.42\left(M e t-W_{\text {ork }}-58.15\right)+1.7 * 10^{-5} * \\
& \left.\operatorname{Met}\left(5867-P_{v}\right)+0.0014 * \operatorname{Met}(34-T)\right]
\end{aligned}
$$

where (Met) is the metabolic rate, (Work) is the active work, $f_{c l}$ (clo) is the garment insulation factor, and $\mathrm{h}_{\mathrm{c}}$ represents the heat transfer coefficient between the clothes and the air. The equations and information to find these variables can be found from standards like (ISO 7730) (Standardization 2005). $\mathrm{T}_{\mathrm{cl}}$ stands for the cloth temperature and it is calculated as:

$T_{c l}=35.7-0.028\left(\right.$ Met $\left.-W_{\text {ork }}\right)-l_{c l}[3.96 *$

$10^{-8} * f_{c l}\left[\left(T_{c l}+273\right)^{4}-\left(T_{R}+273\right)^{4}\right]+f_{c l} *$

$\left.h_{c}\left(T_{c l}-T\right)\right]$

Both $L_{t}$ and Met are used to find the PMV with the following equation:

$$
P M V=(0.303 \exp (-0.036 M e t)+0.028) L_{t}
$$

The value of PMV can indicate the thermal comfort according to the following index (-3: cold, -2 : cool, -1 : slightly cool, 0: neutral, 1: slightly warm, 2: warm, 3: hot). Fanger and Toftum updated the above equations to show the adaption effect for indigenous people who live in houses without an air conditioning system by using the expectancy factor (e), which works as a correction factor (P. Ole Fanger and Toftum 2002). Therefore, equation (4) became:

$$
\begin{aligned}
& P M V_{\text {red }}=e\left[\left(0.303 \exp \left(-0.036 \text { Met }_{\text {red }}\right)+\right.\right. \\
& 0.028)] L_{t}
\end{aligned}
$$

Met $_{\text {red }}$ is the reduced value of Met and it is used to represent the fact that humans living in hot climates tend to be less active. Stavrakakis et al (Stavrakakis et al. 2008) used the following set of equations to find the value of Met $_{\text {red }}$,

Met $_{\text {red }}=$
$\left\{\begin{array}{l}-0.067 * P M V+\text { Met } \quad \text { for } P M V \in(0,1) \\ -0.067 * P M V+1.004 * \text { Met for } P M V \in(1,2) \\ -0.067 * P M V+1.013 * \text { Met for } P M V \in(2,3)\end{array}\right.$

The Predicted Percentage of Dissatisfied (PPD) is widely used with PMV to show the percentage of people that may be feeling discomfort. However, PPD was not considered in this study due to the limited available space and the quantitative nature of this equation.

\section{RESULTS}

During the initial survey for the house, it was noticed that the design of the house is different from what had been found in the north of the Arabian Peninsula. For example, the ventilation in traditional houses in Baghdad and Iran mainly depend on the windcatcher and courtyard. In these countries, the houses are closed from three directions by adjacent houses and overlook into a narrow alleyway. This is not the case in the chosen house in Al-Batinah region. Furthermore, the courtyard is covered with a wooden structure, which suggests that it may be covered during hot weather days. Accordingly, the main source for the airflow is openings, as shown in Figure 4. Here, the air begins 
flowing from the front windows, looping in the rooms, and goes out through the vents to the gallery and the courtyard, and these effects are extended from the first level to the ground level.

Another feature of this building is the design of the roof's parapet wall. In the house, many slit openings were used and were located just above the roof to increase the airflow near the upper surface of the roof. This is important because the roof is usually hotter than the rest of the building and the ambient air due to solar radiation. This extra flow of air can cool it back to a slightly higher temperature than the ambient temperature. Furthermore, at night, the roof will lose heat to the sky, making it cooler and cool the air above; this makes the air heavier and can sink easily through the courtyard to the rest of the house. The parapet's edge has a zigzag shape and induces air movement (i.e., the Bernoulli Effect), as shown in Figure 5. This effect is important at night when the residents use the roof to sleep during the summer.

Figure 6 shows the airflow in the room (FR1), which is the front room on the first level, where the air enters from the windows between the front gallery and the room. The air circulates then leaves the room through the door and vents toward the courtyard or through external vents and windows to the outside. Figure 6 shows that the values of thermal comfort and air velocity changed locally and that the lowest values are near the windows and in the path of the air, which shows the importance of having as many windows as possible near the places of the residents' setting.

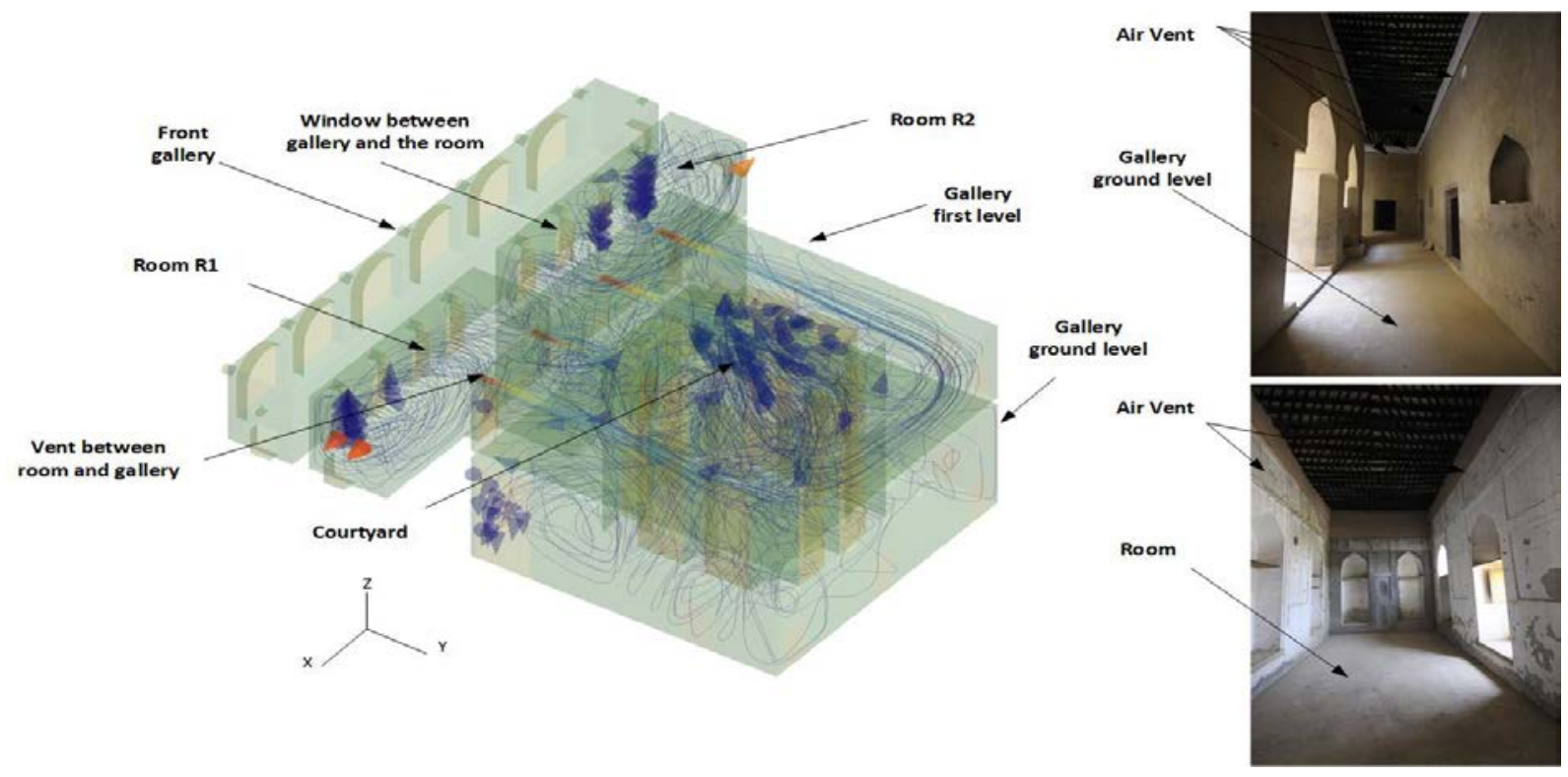

Figure 4. The airflow from the room to the house's core.

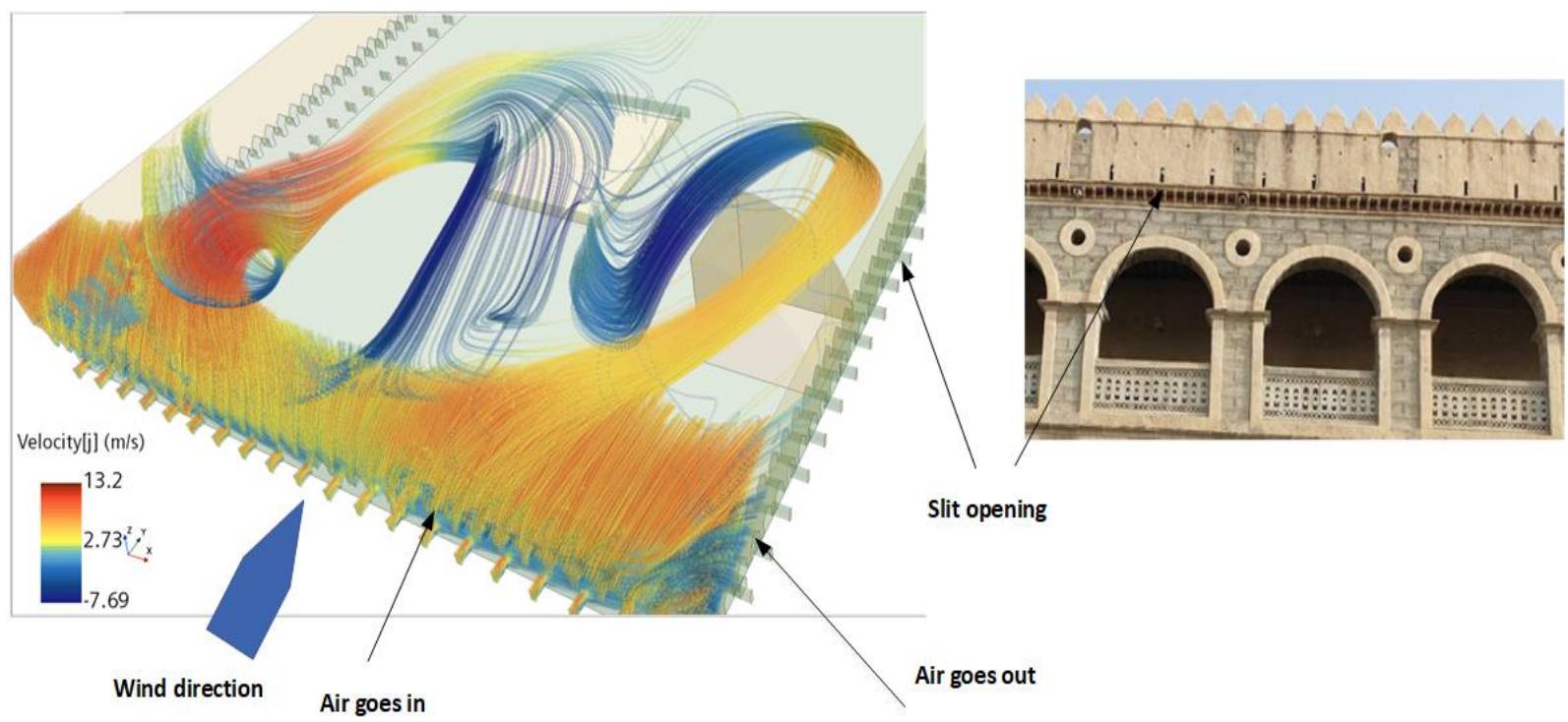


Figure 5. The air velocity is distributed above the roof by using a streamline.

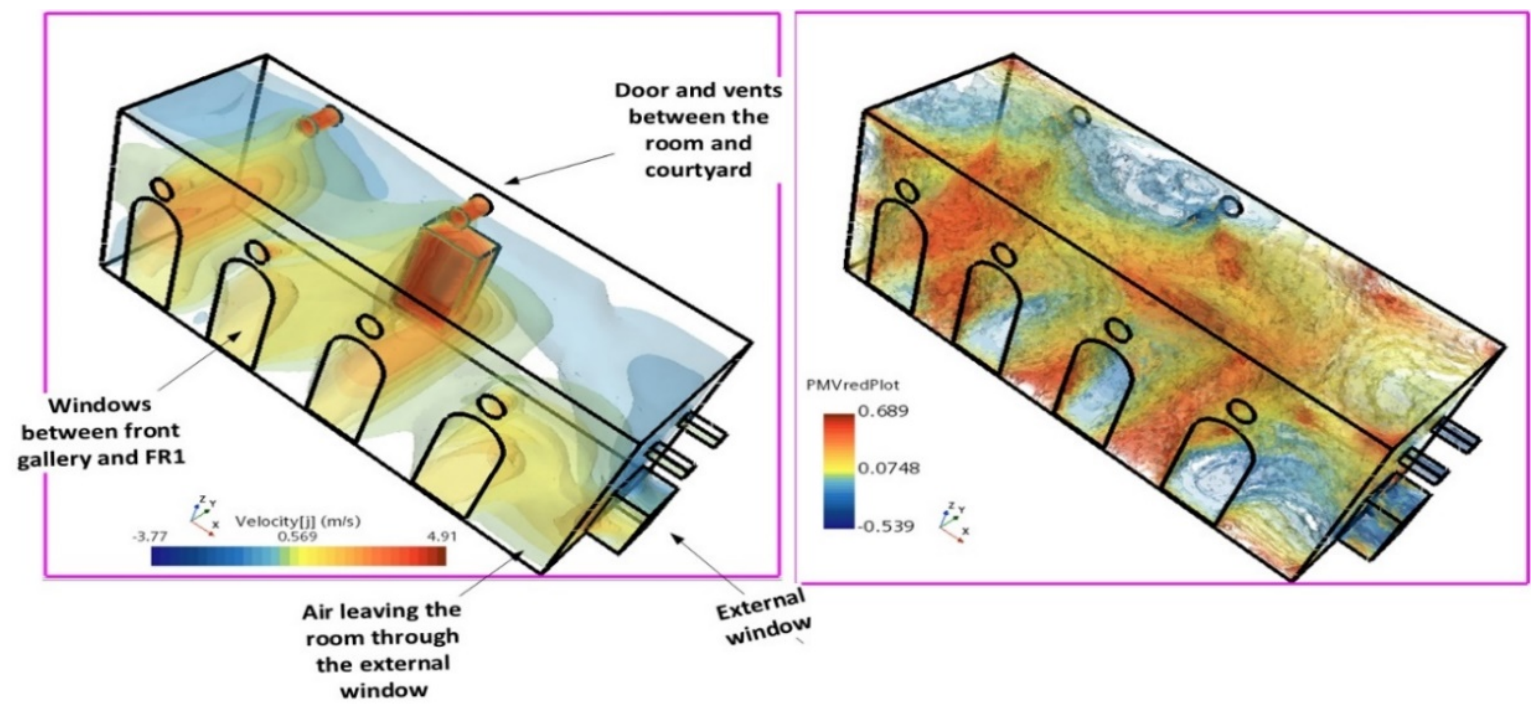

Figure 6. (Left) the component of air velocity in the normal direction, (Right) the value of adaptive PMV.
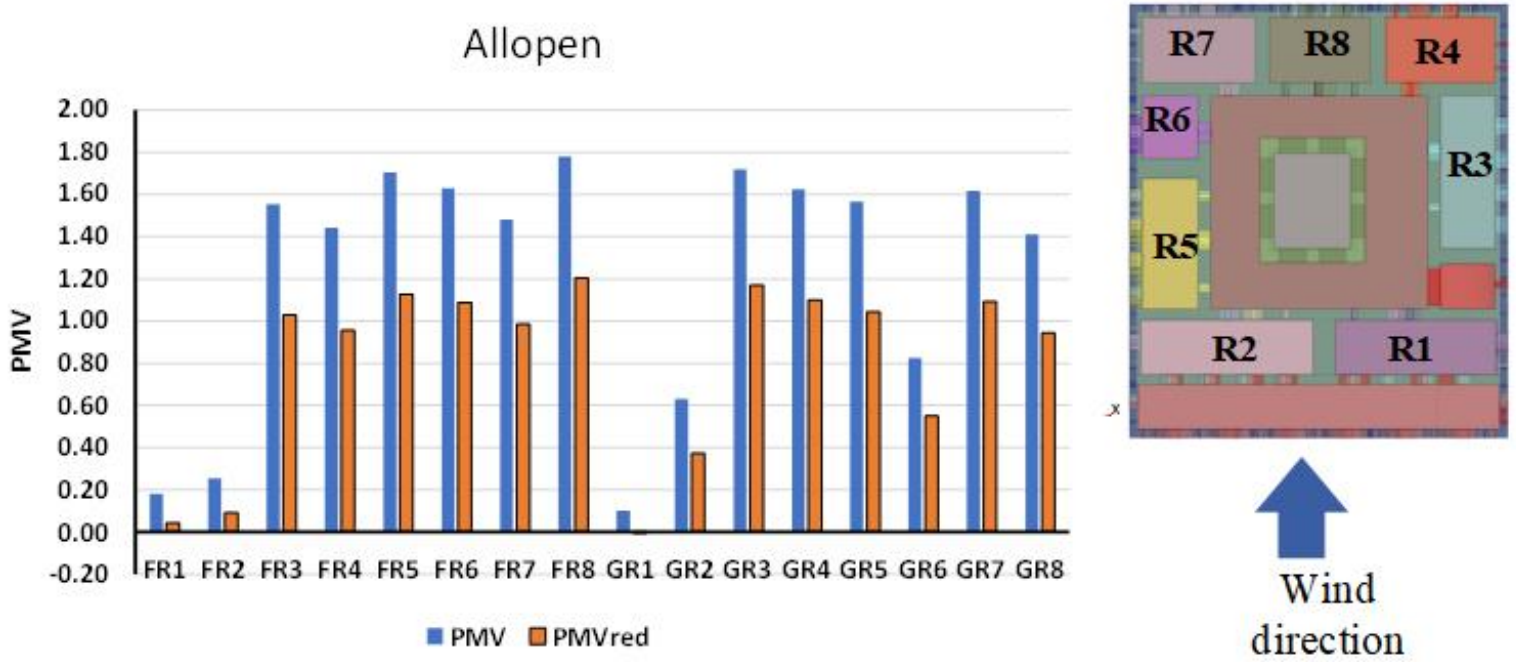

Figure 7. The predicated volume average values for PMV in various rooms of the house.

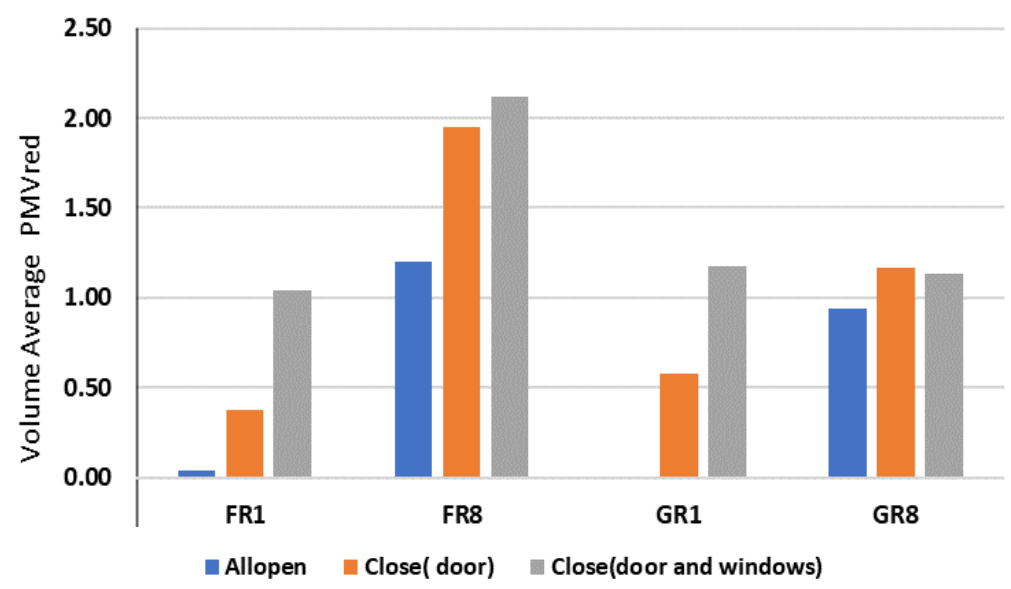

Figure 8. The predicated volume average values for PMV in various rooms of the house with different cases. 
The prediction for thermal comfort is shown in Figure 7 for the case of keeping all the windows and doors open (Allopen case), where the letter F refers to the first level and $G$ refers to the ground level and the right side of the Figure shows the distribution of the rooms. The outdoor air temperature is relatively lower than the initial indoor air in the rooms to simulate the conditions during the breezes. The air flows from rooms R2 and R1 toward the gallery and courtyard to back rooms like R7, R8, and R4. The air in its path toward the back of the house will gain heat, and its temperature will rise, making the values of PMV higher in the back rooms. So, it is better to have a limited air connection between the core of the house (gallery and courtyard) and the surrounding spaces, which can explain why there are no windows between the rooms and the courtyard. The role of external windows is shown in room GR3, where no windows or vents on exterior walls and has only a door and vents on the courtyard side. This is not enough to introduce enough air to cool the room and enhance the values of PMV. Similar conditions happened in lateral rooms like R5 and R7, but with external windows; however, the air passes parallel to the outer opening without penetrating the rooms. The Figure also shows the difference between the normal and adaptive values of PMV. The adaptive comfort shows that indigenous residents feel between neutral to slightly warm toward the conditions in the house without using AC units. However, it is still needed to examine the PMV under more extreme conditions like in mid-summer in future research and the passive techniques used to adapt to such conditions.

The present study compared different situations like keeping all the doors and windows opened (Allopen), opening only the windows (close (door)), and closing the windows and doors (close (door and windows)). Figure 8 shows the lowest values for PMV are when all the openings are open (Allopen). However, the rooms in the back of the house present a slight difference compared to rooms in the front. Again, this demonstrates the need to have many windows on the house's external walls with fewer or no windows on the internal walls.

\section{CONCLUSION}

This research attempted to address the question of thermal comfort and how it is affected in spaces of traditional architecture in Al-Batinah region, and how can these architectural solutions be employed to achieve more sustainable designs for contemporary houses. There are few papers on the numerical simulation of traditional houses in Oman despite its unique design compared to other traditional houses in the region. The study concluded that there is a need for airflow to provide indoor thermal comfort. It has been shown that this airflow is better generated when more windows exist on the external perimeters than on the interior ones. The thermal comfort can vary with the room location.

Additionally, the thermal conditions in the house's core are more dependent on the rooms than the outdoor air. There are many other building elements in other houses that could be studied in future research. Similarly, other aspects could also be examined, such as the role of the airspeed, temperature, direction, and relative humidity.

\section{CONFLICT OF INTEREST}

The authors declare no conflicts of interest

\section{FUNDING}

The research described herein was funded under an internal grant programme (IG/ENG/CAED/20/02) from Sultan Qaboos University, Oman. The authors gratefully acknowledge the continuous support of the university and the Department of Civil and Architectural Engineering.

\section{REFERENCES}

Abdul Majid, Noor, Nozomi Takagi, Shuichi Hokoi, Sri Ekasiwi, and Tomoko Uno. 2014. "Field Survey of Air Conditioner Temperature Settings in a Hot, Dry Climate (Oman).” HVAC\&R Research 20. https://doi.org/10.1080/10789669.2014.953845.

Alalouch, Chaham, Saleh Al-Saadi, Husam AlWaer, and Kamel Al-Khaled. 2019. "Energy Saving Potential for Residential Buildings in Hot Climates: The Case of Oman.” Sustainable Cities and Society 46 (April): 101442. https://doi.org/10.1016 /j.scs.2019.101442.

Al-Hinai, H., W. J. Batty, and S. D. Probert. 1993. "Vernacular Architecture of Oman: Features That Enhance Thermal Comfort Achieved within Buildings.” Applied Energy 44 (3): 233-58. https://doi.org/10.1016/0306-2619(93)90019-L.

Almatawa, M. S., A. A. Elmualim, and E. A. Essah. 2012. "Passive and Active Hybrid Approach to Building Design in Saudi Arabia.” In , 163-74. Kos, Greece. https://doi.org/10.2495/ARC120151.

Al-Saadi, Saleh N. 2021. "Pragmatic Retrofitting Strategies for Improving Thermal, Energy, and Economic Performance of an Institutional Building in a Cooling-Dominated Climate.” Journal of Building Engineering 44: 103326. https://doi.org/10.1016/j.jobe.2021.103326.

Al-Saadi, Saleh N., and Khalifa S. Al-Jabri. 2020. "Optimization of Envelope Design for Housing in Hot Climates Using a Genetic Algorithm (GA) Computational Approach.” Journal of Building Engineering 32: 101712. https://doi.org/10.1016/j.jobe.2020.101712.

Benkari, N. 2017. "The Defensive Vernacular Settlements in Oman, a Contextual Study." International Journal of Heritage Architecture: Studies, Repairs and Maintence 1 (2): 175-84. 
https://doi.org/10.2495/HA-V1-N2-175-184.

Benkari, Naima. 2015. “Wadi Al-Ma’awil: Hujrat Msalmat Documentation \& Heritage Management Plan.” Muscat.

BLAY, D. 1992. "Confined Turbulent Mixed Convection in the Presence of Horizontal Buoyant Wall Jet.” HTD Vol.213, Fundamentals of Mixed Convection. https://ci.nii.ac.jp/naid/10005732529/en.

Damlūji, S. S. 1998. The Architecture of Oman. Garnet.

https://books.google.com.om/books?id=t7JgQgA ACAAJ.

Egan, M.D. 1975. Concepts in Thermal Comfort. Prentice Hall PTR. https://books.google.com .om/books?id=gDpSAAAAMAAJ.

Fanger. 1970. Thermal Comfort: Analysis and Applications in Environmental Engineering. Danish Technical Press. https://books.google.com. om/books?id=SOFSAAAAMAAJ.

Fanger, P. Ole, and Jørn Toftum. 2002. "Extension of the PMV Model to Non-Air-Conditioned Buildings in Warm Climates.” Energy and Buildings 34 (6): 533-36. https://doi.org/10.1016/S0378-7788(02) 00003-8.

Franke, Jörg, Antti Hellsten, Heinke Schlünzen, and Bertrand Carissimo. 2011. "The COST 732 Best Practice Guideline for CFD Simulation of Flows in the Urban Environment: A Summary." International Journal of Environment and Pollution 44: 419-27. https://doi.org/10.1504 /IJEP.2011.038443.

Gharibi, Hamad Al. 2014. "Urban Growth from Patchwork to Sustainability. Case Study: Muscat," 323.

Givoni, B. 1998. Climate Considerations in Building and Urban Design. Wiley. https://books.google. com.om/books?id=MGkArZ_berAC.

Heidari, Abolfazl, Sadra Sahebzadeh, and Zahra Dalvand. 2017. "Natural Ventilation in Vernacular Architecture of Sistan, Iran; Classification and CFD Study of Compound Rooms.” Sustainability 9 (6). https://doi.org/10.3390/su9061048.

Hooff, T. van, and B. Blocken. 2010. "Coupled Urban Wind Flow and Indoor Natural Ventilation Modelling on a High-Resolution Grid: A Case Study for the Amsterdam ArenA Stadium." Environmental Modelling \& Software 25 (1): 5165. https://doi.org/10.1016/j.envsoft.2009.07.008.

Kay, Shirley. 1991. Architectural Heritage of the Gulf. Motivate Pub.

Krarti, Moncef, and Kankana Dubey. 2017. “Energy Productivity Evaluation of Large Scale Building Energy Efficiency Programs for Oman.” Sustainable Cities and Society 29 (February): 1222. https://doi.org/10.1016/j.scs.2016.11.009.
Meddah, M. S., N. Benkari, S. N. Al-Saadi, and Y. Al Maktoumi. 2020. "Sarooj Mortar: From a Traditional Building Material to an Engineered Pozzolan -Mechanical and Thermal Properties Study." Journal of Building Engineering 32 (November): $\quad 101754 . \quad$ https://doi.org/10.1016 /j.jobe.2020.101754.

Nicol, Fergus. 1974. "An Analysis of Some Observations of Thermal Comfort in Roorkee, India and Baghdad, Iraq." Annals of Human Biology 1 (November): 411-26. https://doi.org/ 10.1080/03014467400000441.

Rajapaksha, I., H. Nagai, and M. Okumiya. 2003. “A Ventilated Courtyard as a Passive Cooling Strategy in the Warm Humid Tropics.” Renewable Energy 28 (11): 1755-78.

Richards, P. J, and R. P Hoxey. 1993. "Appropriate Boundary Conditions for Computational Wind Engineering Models Using the K- $\epsilon$ Turbulence Model." Journal of Wind Engineering and Industrial Aerodynamics, Proceedings of the 1st International on Computational Wind Engineering, 46-47 (August): 145-53. https://doi.org/10.1016 /0167-6105(93)90124-7.

Scudo, Gianni. 1988. "Climatic Design in the Arab Courtyard House.” Environmental Design: Journal of the Islamic Environmental Design Research Centre 12.

Shao, L, R Walker, and M Woolliscroft. 1993. "Natural Ventilation via Courtyards: The Application of CFD.” In AIVC. Copenhagen. https://www.aivc.org /resource/natural-ventilation-courtyardsapplication-cfd.

Shih, Tsan-Hsing, William W. Liou, Aamir Shabbir, Zhigang Yang, and Jiang Zhu. 1995. "A New K- $\epsilon$ Eddy Viscosity Model for High Reynolds Number Turbulent Flows." Computers \& Fluids 24 (3): 227-38. https://doi.org/10.1016/00457930(94)00032-T.

Standardization, International Organization for. 2005. ISO 7730 2005-11-15 Ergonomics of the Thermal Environment: Analytical Determination and Interpretation of Thermal Comfort Using Calculation of the PMV and PPD Indices and Local Thermal Comfort Criteria. ISO. https://books.google.com.om/books?id=p3YcoAE ACAAJ.

Stavrakakis, G.M., Maria Koukou, Vrachopoulos Michail, and N.C. Markatos. 2008. "Natural CrossVentilation in Buildings: Building-Scale Experiments, Numerical Simulations and Thermal Comfort Evaluation.” Energy and Buildings 40 (January): 1666-81.

Szokolay, S. 2012. Introduction to Architectural Science. Taylor \& Francis. https://books.google. com.om/books?id=RuFt 